\title{
A BEGINNER'S GUIDE TO SPACE TRAVEL AND SEAFOOD
}

\section{Are you ready for a new life?}

\section{BY STEVEN FISCHER}

$\mathrm{Y}$ $Y^{m=1+2}$

They won't tell you that at the Travel Bureau or in those holos the Colony Department spews out, but it's good advice. You can trust me.

Listen, I get it. I was young once, too. All spitfire and stardust and dreams of going someplace new. Wide-eyed at the first travel agent who rolled by the arcology in a shiny new hover skid.

They're slick, those recruiters. Reel you in with pretty pictures of worlds that haven't been bulldozed and butchered. Planets that still boast fresh water and trees. Places you can stretch out your arms without bumping into another carbon breather. Worlds where you can find that special someone and snag yourself a place in the hills. Maybe pop out an offspring or two. Hell, pop out as many as you'd like; there aren't population restrictions yet. I get it, like I said.

Plus, the flight won't be so bad. The trip's 1,000 years, but you'll be asleep almost the whole time, comfortable as a chefbot in a kitchen, nestled into your own little fugue. Just pull the lid down, pump some cryo in your veins, and wake up once or twice for your semi-centennial health check. Then, a few quick naps later, you wake up for good on your own personal Eden, right?

Wrong.

Here's what they don't tell you. Two hundred years into that little nap of yours, another arkship leaves for your new home sweet home. Only this one was built two centuries after yours. All the newest gizmos and gadgets. Fugue chambers with double the legroom. Health scanners so efficient you can forget the old turn-and-cough at your next check-up. A gravity drive that's twice as fast as yours.

What's that? Twice as fast? But didn't the agent tell you that your ship was state of

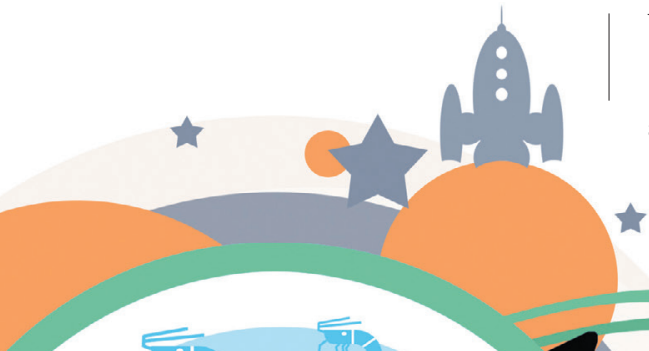

your degree is a millennium out of date.

$\mathrm{Oh}$, and by the way, ship three left 100 years after ship two and is scheduled to arrive next, so you might as well forget that smoothie-stand job; they've got 300 years of education on you.

Best case, maybe you'll scrounge up the cash to buy yourself a little vendor cart. Sell some paella to the folks who were smarter than you, and the tourists who were even smarter than them. Because if there's one thing they haven't been able to improve on, it's a good pan of paella, and for all the lies that recruiter told you, planet Horriblyobviousattempttoinvokenostalgiaforadeadearth does have some damn fine shrimp. And maybe, just maybe you'll have the chance to chat up some young kid and stop them from making the same mistake you did.

So trust me. Put the bowl down, quit stuffing your face, and toss that ticket in your hand straight into the trash. Even better, burn it.

I know. You didn't come this far just to give up, and some old codger's words aren't going to be enough to erase those pictures of Perfectlyfocusgroupedtoappealtothelargestdemographic. I get it. Well, today's your lucky day.

See that hover skid across the street? The the art? That the principles of physics suggested - hell, demanded - it would be the fastest piece of titanium in the galaxy for 5,000 years? Well, there were some folks a few millennia ago who thought they'd built a boat that couldn't sink. I bet you can guess how that one turned out.

What that means is by the time your old clunker arrives on planet Whatevercraptheynamedit, ship number two has already been there for 300 years. Instead of waking up as an intrepid pioneer, you're going to be serving nutrient smoothies for minimum wage
D NATURE.COM Follow Futures:

y @NatureFutures $f$ go.nature.com/mtoodm to ship two's greatgreat-grandkids.

What's that? You were an engineer? That's nice. Too bad guy inside is a good friend of mine. Runs a little transportation service of his own. Newest tech, fastest ships, guaranteed. Don't even run on a gravity drive. One hundred per cent singularity propulsion. They can get you where you're going in a quarter of the time. That's only 250 years.

And let me guarantee you, there is no way anyone's going to come up with something faster by then. $\mathbf{a}$

Steven Fischer is a medical resident living in the Pacific Northwest. When he's not cracking open a textbook (or a patient's thorax), he can be found exploring the Cascades by bike, boat or boot. You can read more of his work at www.stevenbfischer.com. 